\title{
Distribution of Wolbachia among the guild associated with the parthenogenetic gall wasp Diplolepis rosae
}

\author{
MENNO SCHILTHUIZEN* \& RICHARD STOUTHAMER \\ Department of Entomology, Wageningen Agricultural University, PO Box 8031, NL-6700 EH Wageningen, The \\ Netherlands
}

\begin{abstract}
Symbionts of the genus Wolbachia, which cause reproductive alterations in insects, are suspected to pass regularly from one host lineage to another. One possible route for such 'horizontal transmission' is via parasitization. Here, we study this hypothesis in a complex guild of specialized parasitoids and inquilines, associated with the parthenogenetic, Wolbachia-infected gall wasp Diplolepis rosae. Diplolepis rosae galls ('bedeguar galls') were collected at three localities in The Netherlands and Germany. Specimens of most guild members were obtained. Using molecular techniques, the presence of Wolbachia was detected in five members of the assemblage. Three of these, Torymus bedeguaris, Habrocytus bedeguaris and D. rosae carried a Wolbachia belonging to the same subgroup (type I). A phylogenetic analysis was performed on DNA sequences from the Fts $Z$ gene from these three Wolbachias. The analysis showed that the three strains do not cluster closely together, which indicates that the parasitoids have not acquired their Wolbachia from their host. We could not detect host-to-parasitoid transmission in this assemblage (where interactions are both specific, frequent, and possibly ancient).
\end{abstract}

Keywords: Chalcidoidea, Cynipidae, FtsZ, horizontal transmission, molecular phylogenetics, parthenogenesis-associated symbionts.

\section{Introduction}

The cynipid Diplolepis rosae (L.) is a common holarctic species, which produces conspicuous galls on wild roses (Rosa spp.). The wasp has one (parthenogenetic) generation per year, which emerges from the galls in spring (although some specimens may take more than one year to develop). In addition, a variety of other hymenopterans also develop in the galls. These form a characteristic assemblage of species composed of parasitoids of $D$. rosae, inquilines (cynipids which use other gall wasps' galls for their own benefit), parasitoids of the inquilines, and hyperparasitoids. This assemblage has been studied and described by various authors (Blair, 1943, 1944, 1945, 1951; Schröder, 1967; Nordlander, 1973; Askew, 1980; Stille, 1984; Redfern \& Askew, 1992). Figure 1, which is based on these studies, gives a visual summary of the ecological relationships among the various species within this complex.

\footnotetext{
*Correspondence. Present address: Department of Genetics, Dreijenlaan 2, NL-6703 HA Wageningen, The Netherlands. E-mail: menno.schilthuizen@fungen.el.wau.nl
}

One additional organism in the guild associated with $D$. rosae is the endosymbiotic bacterium Wolbachia. Recently, using diagnostic PCR Van Meer et al. (1995) have demonstrated that the species is infected with this symbiont. Stouthamer \& Kazmer (1994) have suggested that Wolbachia, which is known to induce parthenogenesis in other hymenopterans (Stouthamer et al., 1993; Zchori-Fein et al., 1994; Van Meer et al., 1995; Pijls et al., 1996), may also be responsible for unisexuality in $D$. rosae. Earlier studies by Stille \& Dävring (1980) have shown that, as in Trichogramma (Stouthamer \& Kazmer, 1994) and Muscidifurax (Legner, 1985), the restoration of diploidy in the (initially haploid) $D$. rosae egg is achieved by gamete duplication. This suggests that $D$. rosae owes its parthenogenetic mode of reproduction to the symbiont.

One well established peculiarity of Wolbachia is its phylogenetic distribution. The bacterium is normally vertically transmitted (i.e. from mother to offspring). One would thus expect the evolutionary fates of host and symbiont to be tightly linked. However, molecular phylogenetic studies have shown that host and symbiont phylogenies are incongruent (O’Neill et al., 1992; 
Fig. 1 Host-parasitoid relationships among the bedeguar-gall guild (after Nordlander, 1973; Redfern \& Askew, 1992). The large cells in the gall are occupied by the gall-maker, Diplolepis rosae (Dr); the small cells by the inquiline, Periclistus brandtii $(\mathrm{Pb})$. Arrows point from parasitoid to host. Further abbreviations: Om, Orthopelma mediator; Hb, Habrocytus bedeguaris; Tb, Torymus bedeguaris; Gs, Glyphomerus stigma; Er, Eurytoma rosae; $\mathrm{Ci}$, Caenacis inflexa.

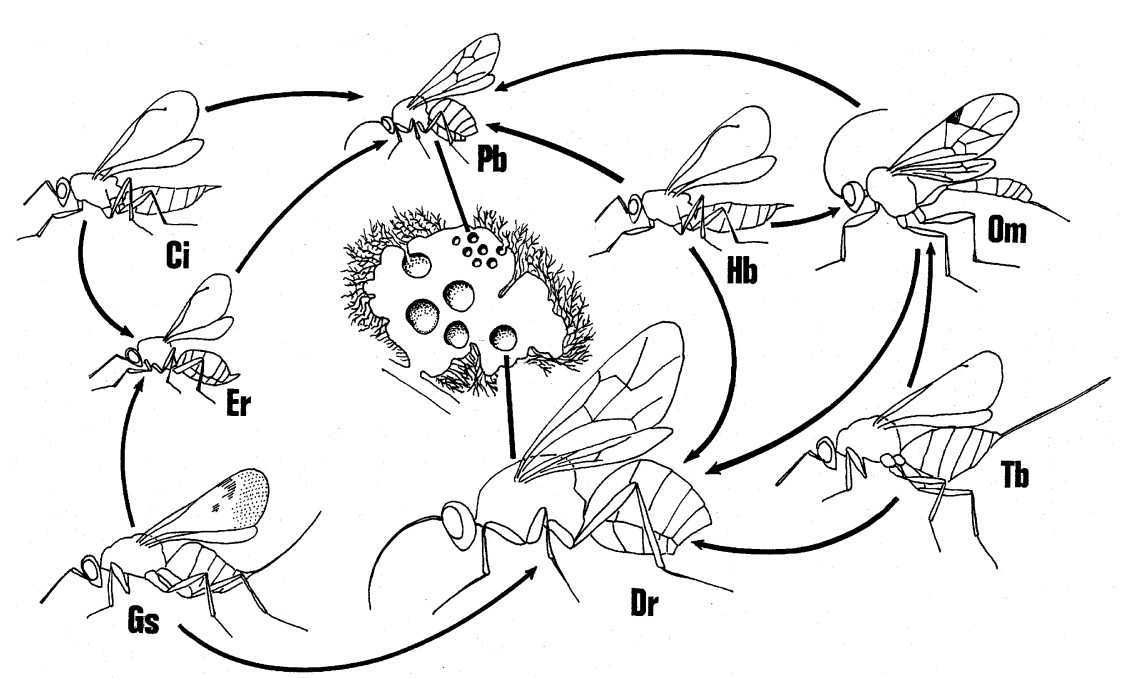

Stouthamer et al., 1993; Werren et al., 1995; Schilthuizen \& Stouthamer, 1997). This suggests that horizontal transmission must frequently have taken place, obscuring any phylogenetic patterns. Some authors (e.g. Werren et al., 1995) have suggested that attack of an infected insect by parasitic insects might be a route for such horizontal transmission.

In this paper, we test this hypothesis for the $D$. rosae assemblage. We use diagnostic PCR to detect the presence of Wolbachia in D. rosae and members of the complex surrounding it. We then perform a molecular phylogenetic analysis to determine the relatedness among these strains.

\section{Materials and methods}

In the spring of 1995 and 1996, we collected $\approx 40$ bedeguar galls at Wageningen and Heelsum (The Netherlands) and Bad Hersfeld (Germany). We placed the galls in plastic containers in which, over the course of the following weeks, hosts, inquilines and parasitoids emerged. The animals were collected regularly and frozen at $-20^{\circ} \mathrm{C}$ until further treatment.

Specimens were either identified while frozen or were first placed in $100 \%$ ethanol and then identified. In both cases, after identification, their DNA was extracted using a standard phenol/chloroform technique followed by NaAc-ethanol precipitation (see Stouthamer et al., 1993). Voucher specimens were deposited in the insect collection of the Department of Entomology, Wageningen Agricultural University.

We used the Wolbachia-specific PCR-primers for the Fts $Z$ gene, which were developed by Holden et al. (1993) to determine the presence of Wolbachia in the material. In case of a positive result we used the PCR-primers from Werren et al. (1995) to distinguish between two subgroups of Wolbachia, termed types I and II (Stouthamer et al., 1993) or groups B and A, respectively (Werren et al., 1995). Each PCR-reaction was carried out in a $50 \mu \mathrm{L}$ reaction volume, using, apart from standard conditions, $0.5 \mathrm{U}$ SuperTth DNA-polymerase, $5 \mathrm{pmol}$ of each primer, and a final $\left[\mathrm{Mg}^{2+}\right]$ of $2.8 \mathrm{~mm}$. As controls, PCR-reactions were also performed on blanks and on DNA from Nasonia vitripennis, a pteromalid known to be infected with both types of Wolbachia.

Because D. rosae was known to be infected with type I Wolbachia only (van Meer et al., 1995), and because of the generally very low variability within the type II Wolbachia, we only sequenced type I PCR-products. These were excised from agarose gels, extracted by the 'freeze-squeeze technique' (Sambrook et al., 1989) and cloned in a $\mathrm{pCR}^{\mathrm{TM}} 2.1$ T-tailed vector (Invitrogen). Recombinants were checked for the presence of the correct insert by direct colony screening with PCR, as recommended by the manufacturer. Positive colonies were then grown overnight in liquid medium, and plasmid DNA was isolated using QIAPrep spin columns (QIAGEN). The insert was sequenced in both directions on an ABI automated sequencer. From each infected species, three or four clones were sequenced. The sequences were deposited in the GenBank database under accession numbers U83884-U83894.

We aligned our (11) sequences with 15 other type I Fts $Z$-sequences from GenBank (accession numbers U59696, U28193, U28197-U28200, U28202-U28206, 
U28208-U28211), using the ESEE 3.0s sequence editor (Cabot, 1995). We left end-unaligned regions untrimmed.

Phylogenetic analysis was performed with the use of PAUP 3.1 (Swofford, 1993). We performed a heuristic search with 10 different random addition sequences. A majority rule consensus was calculated over the most parsimonious trees. Bootstrapping was carried out 100 times. Trees were rooted with the sequence from Aramigus tesselatus as the outgroup (based on the analysis by Werren et al., 1995).

\section{Results}

All members of the $D$. rosae assemblage commonly reported for Northern Europe were obtained, other than Eurytoma rosae Nees (Table 1). Torymus rubi (Schrank), of which a single specimen was recorded, is probably not a regular parasitoid of $D$. rosae (M. J. Gijswijt, pers. comm.; see also Askew, 1980).

Our PCR analysis showed the presence of type I Wolbachia in all sampled $D$. rosae and its parasitoids Torymus bedeguaris (L.) and Habrocytus bedeguaris Thomson. Type II Wolbachia was detected in the single specimen of Torymus rubi, and in Orthopelma mediator (Thunberg) from the locality Heelsum only. Both other $O$. mediator populations, the inquiline Periclistus brandtii (Ratzeburg), its parasite Caenacis inflexa (Ratzeburg) and the D. rosae parasitoid
Glyphomerus stigma (F.) were found not to be infected.

The DNA alignment contained 52 informative nucleotide positions. The phylogenetic analysis produced a large number of equally parsimonious trees of length 150 and a consistency index (CI; Kluge \& Farris, 1969) of 0.83 . Out of 3000, we selected the tree with the best correspondence to the majority-rule consensus (Fig. 2). The analysis showed that the three species infected with type I Wolbachia do not carry identical strains of the symbiont. Instead, each contains a strain that falls within a different clade on the tree. And although the bootstrap values are generally not very high, there are two observations that make us confident of this nonmonophyly. First, in none of the most parsimonious trees did these strains form a monophyletic group. Secondly, when searches were carried out with monophyly for this group constrained, they yielded trees that were at least five steps less parsimonious than when such a monophyly was not enforced.

\section{Discussion}

The PCR survey showed that, apart from $D$. rosae itself, four other members of its assemblage are infected with Wolbachia. However, none of the members of the assemblage carries a Wolbachia that

Table 1 Results from the PCR-survey of Wolbachia-infection in members of the bedeguar-gall guild. With the exception of Diplolepis rosae, where each individual was separately assayed, DNA was mass-extracted from three to five individuals. For the ecological roles of the various species, see Fig. 1. Torymus rubi is probably an accidental parasitoid of $D$. rosae

\begin{tabular}{lcccl}
\hline Species & $\begin{array}{c}\text { Number of } \\
\text { individuals found } \\
\text { in Wageningen }\end{array}$ & $\begin{array}{c}\text { Number of } \\
\text { individuals found } \\
\text { in Heelsum }\end{array}$ & $\begin{array}{c}\text { Number of } \\
\text { individuals found } \\
\text { in Bad Hersfeld }\end{array}$ & Infection status \\
\hline $\begin{array}{l}\text { Diplolepis rosae } \\
\text { (Cynipidae) }\end{array}$ & 19 & 8 & 32 & Type I \\
$\begin{array}{l}\text { Torymus bedeguaris } \\
\text { (Torymidae) }\end{array}$ & $\approx 25$ & $\approx 5$ & 7 & Type I \\
$\begin{array}{l}\text { Torymus rubi } \\
\text { (Torymidae) }\end{array}$ & 0 & 0 & 1 & Type II \\
$\begin{array}{l}\text { Glyphomerus stigma } \\
\text { (Torymidae) }\end{array}$ & 0 & 0 & $\approx 30$ & Not infected \\
$\begin{array}{l}\text { Habrocytus bedeguaris } \\
\text { (Pteromalidae) }\end{array}$ & 0 & 0 & 6 & Type I \\
$\begin{array}{l}\text { Caenacis inflexa } \\
\text { (Pteromalidae) }\end{array}$ & 1 & 0 & 8 & Not infected \\
$\begin{array}{l}\text { Orthopelma mediator } \\
\text { Ichneumonidae) }\end{array}$ & $\approx 30$ & $\approx 15$ & $\approx 40$ & Type II (but only in Heelsum) \\
$\begin{array}{l}\text { Periclistus brandtii } \\
\text { (Cynipidae) }\end{array}$ & 0 & 0 & $\approx 50$ & Not infected \\
\hline
\end{tabular}


Fig. 2 A most parsimonious tree, identical to the majority-rule consensus over all most parsimonious trees, with relevant bootstrap percentages indicated.

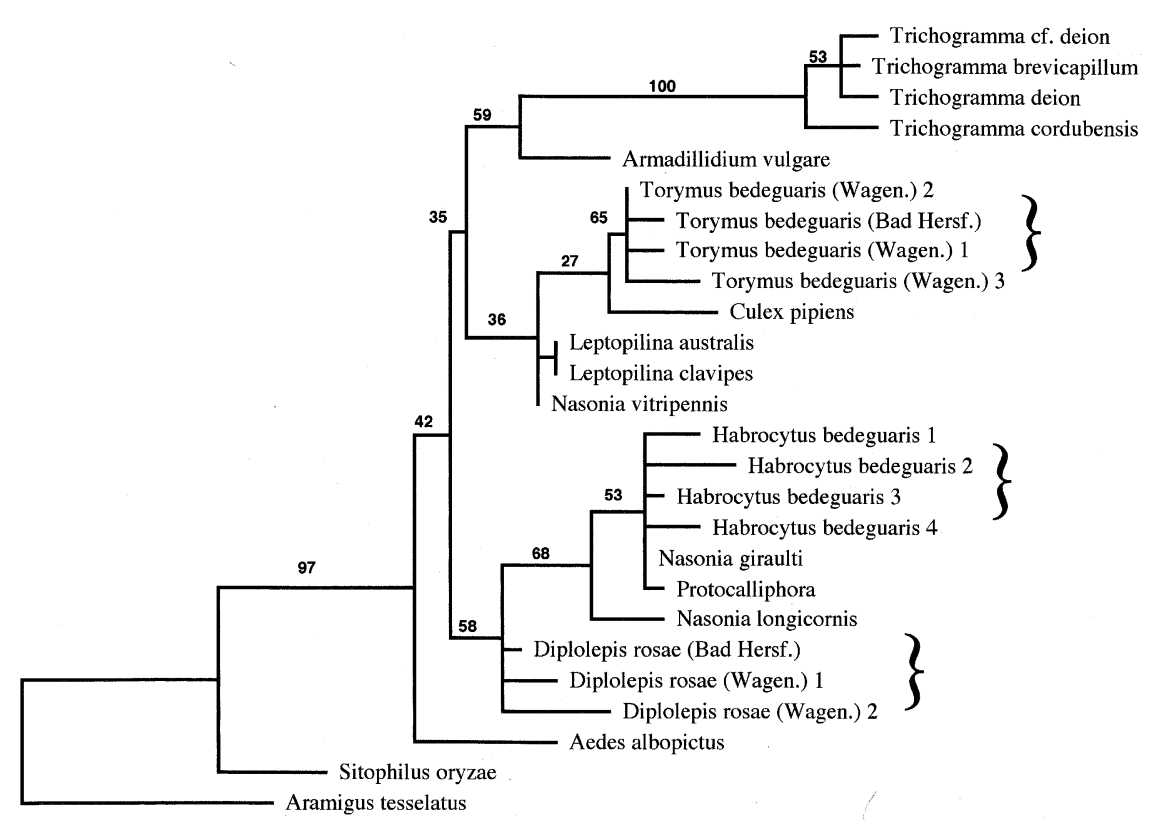

is closely related to the one in D. rosae. Two of them, O. mediator and T. rubi, are infected with symbionts belonging to type II, another subgroup within Wolbachia, whereas the symbionts in T. bedeguaris and $H$. bedeguaris, although they do belong to type I, are placed in clades distinct from the one in D. rosae.

We conclude that the infected members of the assemblage have not acquired their Wolbachia from $D$. rosae, or indeed vice versa, but from elsewhere. This is a striking conclusion, because these parasitoids have a specific and intense relationship with D. rosae (Askew, 1980), which is also likely to be ancient. They are also quite common species. All this should have given ample opportunity for Wolbachia to have passed from host to parasitoid. That they seem not to have done so, appears to weaken the parasitoid hypothesis, or at least its general applicability.

There are some caveats, however. First of all, the association of $D$. rosae with Wolbachia may itself not be very old. Occasionally, male $D$. rosae are found (Kinsey, 1920; Callan, 1940; Stille, 1984). If these are functional, they might give an indication of the length of time during which mutations have been accumulating in male-expressed genes.

Also, successful transfer between host and parasitoids may have taken place only once. If this happened so long ago that apomorphic substitutions have since built up in the parasitoid symbionts, this would explain why the three strains form separate clades in the tree.
Yet, even if any of the above considerations were true, the simple fact remains that we never found the Wolbachia strain from $D$. rosae in any of its parasitoids, which suggests that horizontal transmission occurs very rarely, if at all.

\section{Acknow ledgements}

We thank Jens Bernhardt, Eddy Dijkstra, Frenk van Kan, Marnix van Meer, and Isabel Silva for help in the collecting of bedeguar galls. Yde Jongema, M. J. Gijswijt, and Eddy Dijkstra helped with the identification of the material. Göran Nordlander and five anonymous reviewers are thanked for critically reading the manuscript. All the people in the Stouthamer lab are acknowledged for their comments and support during the development of this study. This work was supported by the research school of Functional Ecology.

\section{References}

ASKEW, R. R. 1980. The diversity of insect communities in leaf-mines and plant galls. J. Anim. Ecol., 49, 817-829.

BLAIR, K. G. 1943. On the rose bedeguar gall and its inhabitants. Ent. Mon. Mag., 79, 231-233.

BLAIR, K. G. 1944. A note on the economy of the rose bedeguar gall, Rhodites rosae L. Proc. South Lond. Ent. Nat. Hist. Soc., 1943-44, 55-59.

BLAIR, K. G. 1945. Notes on the economy of the rose-galls formed by Rhodites (Hymenoptera, Cynipidae). Proc. $R$. Ent. Soc. Lond. A, 20, 26-31. 
BlaIR, K. G. 1951. Eupelmus eurozonus Dahlb. (Hym., Chalcididae) in galls of Rhodites rosae L. (Hym., Cynipidae). Ent. Mon. Mag., 87, 174-175.

САВOT, E. 1995. ESEE. The Eyeball Sequence Editor. Release 3.0s. University of Rochester, Rochester, New York.

CALLAN, E. McC. 1940. On the occurrence of males of Rhodites rosae (L.) (Hymenoptera, Cynipidae). Proc. $R$. Ent. Soc. Lond., A, 15, 21-26.

HOLDEN, P. R., BROOKFIELD, J. F. Y. AND JONES, P. 1993. Cloning and characterization of an FtsZ homologue from a bacterial symbiont of Drosophila melanogaster. Mol. Gen. Genet., 240, 213-220.

KINSEY, A. C. 1920. Life histories of American Cynipidae. Bull. Am. Mus. Nat. Hist., 42, 319-357.

KLUGE, A. G. AND FARRIS, J. S. 1969. Quantitative phyletics and the evolution of the anurans. Syst. Zool., 18, 1-32.

LEGNER, E. F. 1985. Effects of scheduled high temperature on male production in thelytokous Muscidifurax uniraptor. Can. Ent., 117, 383-389.

NORDlAnder, G. 1973. Parasitsteklar i galler av Diplolepis rosae (L.) och D. mayri Schlechtd. (Hym. Cynipidae) (Hym. Ichneumonoidea, Chalcidoidea, Cynipoidea). Ent. Tidskr., 94, 148-176.

O'NEILL, S. L., GIORDANO, R., COLBERT, A. M. E., KARR, T. L. AND ROBERTSON, H. M. 1992. 16S rDNA analysis of the symbionts associated with cytoplasmic incompatibility in insects. Proc. Natl. Acad. Sci. U.S.A., 89, 2699-2702.

PIJLS, J. W. A. M., VAN STEENBERGEN, J. J. AND VAN ALPHEN, J. J. M. 1996. Asexuality cured: the relations and differences between sexual and asexual Apoanagyrus diversicornis. Heredity, 76, 506-513.

REDFERn, M. AND ASKew, R. R. 1992. Plant Galls. Richmond Publishing Company, Slough.

SAMBROOK, J., FRITSCH, E. F. AND MANIATIS, T. 1989. Molecular Cloning: a Laboratory Manual, 2nd edn. Cold Spring Harbor Laboratory Press, NY.

SCHILTHUIZEN, M. AND STOUTHAMER, R. 1997. Horizontal transmission of parthenogenesis-inducing microbes in Trichogramma wasps. Proc. R. Soc. B, 264, 361-366.

SCHRÖDER, D. 1967. Diplolepis (=Rhodites) rosae (L.) (Hym. Cynipidae) and a review of its parasite complex in Europe. Techn. Bull. Commonw. Inst. Biol. Contr., 9, 93-131.

STILLE, B. AND DÄVRING, L. 1980. Meiosis and reproductive strategy in the parthenogenetic gall wasp Diplolepis rosae (L.) (Hymenoptera, Cynipidae). Hereditas, 92, 353-362.

STILLE, B. 1984. The effect of hostplant and parasitoids on the reproductive success of the parthenogenetic gall wasp Diplolepis rosae (Hymenoptera, Cynipidae). Oecologia, 63, 364-369.

STOUTHAMER, R., BREEUWER, J. A. J., LUCK, R. F. AND WERrEN, J. H. 1993. Molecular identification of microorganisms associated with parthenogenesis. Nature, $\mathbf{3 6 1}$, 66-68.

StOUthamer, R. AND KAZMER, D. 1994. Cytogenetics of microbe-associated parthenogenesis and its consequence for gene-flow in Trichogramma wasps. Heredity, 73, 317-327.

SWOFFORD, D. L. 1993. PAUP. Phylogenetic analysis using parsimony. Release 3.1.1. Smithsonian Institution, Washington, DC.

VAN MEER, M. M. M., VAN KAN, F. J. P. M., BREEUWER, J. A. J. AND STOUTHAMER, R. 1995. Identification of symbionts associated with parthenogenesis in Encarsia formosa (Hymenoptera: Aphelinidae) and Diplolepis rosae (Hymenoptera: Cynipidae). Proc. Exp. Appl. Ent. Neth. Ent. Soc., 6, 81-86.

WERREN, J. H., ZHANG, w. AND GUO, L. R. 1995. Evolution and phylogeny of Wolbachia: reproductive parasites of arthropods. Proc. R. Soc. B, 261, 55-71.

ZCHORI-FEIN, E., ROUSH, R. T. AND HUNTER, M. 1994. Male production induced by antibiotic treatment in Encarsia formosa (Hymenoptera: Aphelinidae). Experientia, 48, 102-105. 